JIIP: Jurnal IImiah IImu Pemerintahan

Volume 5, Nomor 2, Tahun 2020

DOI: 10.14710/jiip.v5i2.8516

\title{
Pertarungan Populisme Islam dalam Pemilihan Presiden 2019
}

\author{
Iradhad Taqwa Sihidi ${ }^{1}$, Ali Roziqin ${ }^{2}$, \& Dedik Fitra Suhermanto ${ }^{3}$ \\ ${ }^{1}$ Program Studi Ilmu Pemerintahan, Universitas Muhmmadiyah Malang \\ ${ }^{2}$ Program Studi Ilmu Hubungan Internasional, Universitas Muhmmadiyah Malang
}

Dikirimkan: 16 Juli 2020

Direvisi: 4 September 2020

Diterbitkan: 30 September 2020

\section{INTISARI}

Pilpres 2019 menjadi panggung betapa populisme agama begitu terekpresi sebagai strategi menggaet pemilih. Baik Jokowi dan Prabowo sadar bahwa menonjolkan aspek religiutas melalui strategi politik yang tepat akan memperbesar peluang kemenangan. Tulisan ini berupaya melihat karakteristik penggunaan populisme Islam Jokowi dan Prabowo beserta hasil elektoral yang diperoleh. Dengan menggunakan jenis penelitian kualitaif yang bersifat studi literatur., penulis mengandalkan data-data yang didapatkan melalui studi kepustakaan baik berupa buku, jurnal, koran, majalah, internet dan Website Komisi Pemilihan Umum (KPU) yang mampu memberikan informasi kunci mengenai operasionalisasi populisme Islam Jokowi dan Prabowo. Penelitian ini menunjukan bahwa populisme Islam Jokowi menang karena menguatnya dukungan Nahdatul Ulama (NU) dan kaum nasionalis sehingga unggul telak di Jawa Tengah dan Jawa Timur serta daerah-daerah mayoritas non muslim, diantaranya Papua, Papua Barat, Sulawesi Utara, NTT dan Bali. Sebaliknya Prabowo unggul telak di daerah dengan basis islam kental (puritanisme), seperti Aceh, Sumatera Barat, Kalimantan Selatan, Jawa Barat dan Banten. Pilpres 2019 menunjukan bahwa populisme agama cukup berkontribusi bagi kemenangan kandidat politik sehingga sangat mungkin di masa depan sentimen identitas seperti ini terus diadopsi.

\section{KATA KUNCl}

Jokowi; Islam; pilpres; populisme; Prabowo

\section{Pendahuluan}

Tulisan ini melihat hasil elektoral dari penggunaan politik populisme islam di Indonesia dalam Pemilihan Presiden 2019. Kedua kontestan baik Jokowi sebagai petahana dan Prabowo sebagai penantang terlihat jelas berusaha keras mengkapitalisasi islam sebagai penarik suara. Melalui dinamika politik yang sangat dinamis pilihan Jokowi merangkul Ma'ruf Amin didasarkan pertimbangan rasional meminimilasir stigma anti islam pada dirinya. Sebuah simbol politik akomodatif untuk menonjolkan sisi keislamanya yang selama ini dianggap kurang kuat. Juga disaat bersamaan menjadi startegi efektif untuk menarik gerbong islam moderat khususnya Nahdatul Ulama (NU). Sebaliknya Prabowo menggunakan model populisme yang

\footnotetext{
Korespodensi:
}

Program Studi Ilmu Pemerintahan, Universitas Muhammadiyah Malang, Jl. Raya Tlogomas No.246

Malang, Jawa Timur 65514.

Email: iradhad@umm.ac.id 
berbeda. Antitesa tersebut ditunjukan dengan merangkul gerbong islam "konservatif" untuk menyokong personifikasi figur populisnya sebagai elit religius peyelamat umat islam dari keadaan terpuruk. Islam dipilih sebagai fitur pengikat mengingaat populisme islam begitu mewabah dalam politik elektoral Indonesia belakangan khususnya ditandai dengan kemenangan Anis- Sandi pada Pilkada DKI- Jakarta 2017.

Meskipun sama-sama menggunakan populisme islam namun Jokowi dan Prabowo memiliki karakteristik yang berbeda. Narasi populisme keduanya sangat ditentukan oleh konfigurasi dukungan politik yang didapatkan. Jokowi didukung oleh kekuatan sosial dan politik yang menterjemahkan populisme islam tetap dalam kerangka nasionalisme. Berbeda dengan Prabowo yang visi populisme islamnya sangat dipengaruhi oleh kelompok-kelompok konservatif "anti pancasila". Atas dasar pembedaan itulah hasil elektoralnya pun berbeda. Jokowi unggul telak di ceruk/basis pemilih islam moderat; Jawa Timur dan Jawa Tengah. Atau daerah-daerah mayoritas non islam yang secara garis ideologi politik nyaman dengan islam moderat seperti; Papua, Papua Barat, Nusa Tenggara Timur (NTT), Bali dan Sulawesi Utara. Sebaliknya Prabowo menang telak di daerah-daerah dengan kantong suara keislaman kuat; Sumatera Barat, Kalimantan Selatan, Jawa Barat, Nusa Tenggara Barat, Aceh dan Banten.

Populisme sendiri memang sulit didefinisikan dalam satu terminologi tunggal (Muhtadi, 2019; Panizza, 2005). Istilah ini lentur sehingga menimbulkan banyak tafsir khususnya dalam politik (Moffitt \& Tormey, 2014). Faktor situasi politik, ekonomi dan sosial membuat para ilmuwan memiliki perbedaan untuk mengoperasionalisaikan makna populisme. Ada yang menyakini sebagai gagasan oleh Mudde \& Kaltwasser (2017), wahana diskursif perubahan sosial dalam pandangan Ernesto (2005) atau konflik atas kekuasaan dari perspetif ekonomi politik (Robison \& Hadiz, 2004).

Terlepas dari perbedaan perspektif soal populisme terdapat satu titik dimana populisme dianggap sebagai narasi perlawanan terhadap kekuasaan elit yang berkuasa (Jani, 2017). Tulisan ini sepakat dengan itu bahwa argumentasi dasar populisme sebagai filsafat politik yang bekerja untuk mengkerangkai perjuangan pemimpin demoagog dan karismatik dalam memperjuangkan kepentingan publik (masyarakat terpinggirkan). Populisme memuat diskursus politik yang membagi masyarakat menjadi area antagonistik antara masyarakat versus oligarki. Antagonisme terjadi karena ulah elit korup dan oligarkis yang dituduh menggunakan dominasinya untuk kepentingan mempertahankan dan memperlebar kekayaan mereka sendiri.

Populisme dalam pandangan terfragmentasi dalam dua kutub. Pertama, kalangan yang percaya bahwa populisme sebagai ideologi yang bekerja menggerakan penolakan masyarakat kelas bawah terhadap institusi tradisional (negara). Kedua, yang yakin populisme sebagai startegi elektoral. Lazimnya digunakan oleh politisi yang merepresentasikan diri sebagai agregagator masyarakat banyak untuk menghancurkan elit-elit berkuasa. Pembacaan dalam tulisan ini menggunakan asumsi kedua yang menggunakan populisme sebagai alat mobilitas politik dan jamak digunakan populisme sayap kanan di dunia.

Karena dilekatkan sebagai startegi politik, populisme merupakan bagian dari strategi oportunisme politik untuk menarik simpati pemilih (Conniff, 2012). Dalam melakukan kampanye politik, politisi populis berusaha mengeksploitasi kegelisahan ekonomi dan eksistensi identitas mayoritas sebagai narasi utamanya. Dua persilangan 
yang sempurna mengingat kedua faktor di atas mampu menghimpun kecemasan kolektif warga mayoritas yang merasa semakin terpinggirkan atas persekutuan klik oligarkis politik dan ekonomi. Peluang emosi masa diagregasi oleh politik populis melalui solusi jangka pendek misalnya dengan memberikan tindakan afirmasi-afirmasi ekonomi dan politik bagi mayoritas dan disaat bersamaan mengupayakan ekslusi bagi kelompokkelompok sosial yang dituduh sebagai musuh bersama. Di Indonesia pola demikian tercermin melalui diksi pribumi dan anti china.

Salah satu fleksibilitas populisme karena mampu menempel dalam setiap ideologi seperti sosialisme, nasionalisme, rasisme, anti imperialisme dan neoliberalisme (Mudde \& Kaltwasser, 2017). Lebih jauh Cas Mudde menyebutnya sebagai ideologi yang tipis sehingga implementasinya dapat terjadi dinegara-negara dunia yang memiliki garis ideologi berbeda (Aslanidis, 2016). Misalnya populisme sayap kanan yang saat ini menjangkiti negara-negara eropa dan Amerika Serikat padahal notabenenya lekat dengan kultur liberalisme, Hugo Chaves di Bolivia yang sosialis, Erdogan di Turki (populisme islam) atau Prabowo Subianto dan Joko Widodo di Indonesia.

Sebagai perbandingan ada kemiripan kuat antara populisme yang sedang terjadi di Indonesia dengan di Mesir dan Turki. Ketiganya sedang mengalami fase dimana islam begitu mempengaruhi agenda-agenda politik dan kebijaka di ruang publik. Islam sebagai agama mayoritas di tiga negara tersebut bukan hanya berfungsi sebagai identitas kolektif yang berisi seperangkat aturan soal ritus ibadah dan simbol kesalehan. Lebih dari itu agama menjadi simbol perjuangan perebutan kekuasaan. Indonesia, Mesir dan Turki adalah bukti nyata bahwa agama menjadi sumber kemunculan populisme yang begitu mempengaruhi konfigurasi politik dan perilaku politik elit dan masyarakat.

Tulisan ini hendak melakukan pembacaan kritis pada kemunculan populisme sayap kanan di Indonesia, strategi politik yang dilakukan beserta implikasi politik yang dihasilkan dalam Pemilu Presiden 2019. Kajian ini penting sebab fenomena populisme sayap kanan dengan fokus eksplotasi masif atas sentimen suku, ras dan agama begitu mengejala bukan hanya di Indonesia namun dalam nomenklatur politik global. Arus politik populisme terlihat jelas dengan kehadiran tokoh-tokoh politik populis dunia yang berkuasa atau memperoleh dukungan publik signifikan dengan mengekploitasi secara kecemasan kolektif warga mayoritas atas ketimpangan ekonomi dan ancaman kelangsungan nilai-nilai identitas. Ciri khas populisme sayap kanan terlihat jelas dengan kampanye rasialistik dan anti imigran. Scoot Morison (Australia), Donald Trum (Amerika Serikat), Matteo Slavini (Italia), Boris Johnson (Inggris), Josh Bolzonaro (Brazil) adalah contoh pemimpin berhasil terpilih dengan mengobarkan populisme sayap kanan. Dalam konteks demokrasi secara spesifik penelitian Kenny (2017) membuktikan bahwa populisme di amerika Latin berimplikasi negatif pada penegakan demokrasi konstitusional yang menuntut kesetaraaan dan inklusifitas.

Studi ini berupaya menjelaskan pertarungan ragam populisme islam yang dipergunakan oleh kedua kandidat serta hasil elektoral yang didapatkan. Sudut pandang ini relevan mengingat kajian-kajian tentang hasil akhir dari penggunaan populisme islam dalam kompetisi politik (Pilpres 2019) di Indonesia masih sangat terbatas. Kajian-kajian sebelumnya lebih mengelaborasi fakta dan peristiwa sebelum Pilpres dilaksanakan. Misalnya Kusumo (2017) yang melihat peran vital Gerakan Nasional Pengawal Fatwa MUI dalam menginisiasi dan menggerakan Aksi Bela Islam (ABI) dalam momentum 
pilkada DKI Jakarta 2017 termasuk berkontribusi terhadap kemenangan Anies-Sandi). Temuan berbeda didapatkan Prayogi \& Adela (2019) yang melihat aksi tersebut bukanlah politis namun ekspresi ideologis atas tindakan "penistaan" yang dilakukan Ahok yang kebetulan saat ini menjadi Gubernur DKI Jakarta dan calon petahana. Kajian serupa oleh Jayanto (2019) soal perang wacana populisme islam antara GNPF-Ulama yang totalitas pada semangat islamisasi dan NU yang nasionalis. Kajian lain dilakukan Margiansyah (2019) yang melihat model transformasi politik populisme antara Jokowi dan Prabowo serta menautkanya dengan masa depan demokrasi Indonesia. Terakhir temuan Mudhoffir, Yasih, \& Hakim (2017) sepakat dengan temuan Hadiz (2016) yang melihat bahwa ketidakhadiran aliansi multi kelas yang disokong kaum borjuasi kaya membuat populisme islam di Indonesia tidak berhasil dan justru terserap dalam kekuatan oligarkis. Kedua telaah tersebut dirangkai lebih lanjut oleh Savitri \& Adriyati (2018) sebagai bentuk akumulasi modal kekuatan politik besar dengan memanfaatkan nasionalisme agama yang sangat dekat dengan praktek fasis sebagai instrumen politiknya.

Untuk melihat peta politik hasil penggunaan populisme islam Jokowi dan Prabowo, penelitian ini menggunakan jenis penelitian kualitaif yang bersifat studi literatur. Data-data utama didapatkan melalui studi kepustakaan/literatur baik berupa buku, jurnal, koran, majalah, internet dan Website Komisi Pemilihan Umum (KPU) yang mampu memberikan informasi kunci mengenai operasionalisasi populisme Islam Jokowi dan Prabowo. Agar memberikan kesimpulan yang memadai, model deskriptif menjadi alat analisa yang digunakan. Populisme islam selanjutnya menjadi landasan teoritis untuk memeriksa secara lebih terperinci hasil elektoral Pilpres 2019.

\section{Populisme Islam Jokowi dan Prabowo}

Kehadiran populisme islam dalam politik negara-negara muslim termasuk indonesia dapat dibaca sebagai upaya mendesakan nilai-nilai agama di ruang publik. Agama diharapkan dapat menjadi senjata ampuh untuk merespon kapitalisme global yang penuh kontradiski Hadiz (2013) karena melahirkan ketimpangan dan kemiskinan. Lebih jauh Hadiz menjelaskan bahwa islam yang mengajarkan keadilan dan pemerataan dapat digunakan sebagai alternatif menghancurkan kapitalisme yang ingkar atas janjinya: pembangunan ekonomi berkeadlian dan kesejahteraan. Untuk mendapatkan kontrol tersebut maka kekuasaan negara harus direbut.

Karena sifatnya politis didalamnya ada gabungan aliansi kelas dengan kepentingan aktor yang juga beragam Hadiz (2016) selanjutnya dengan sengaja menglorifikasi islam sebagai pengikatnya. Islam berkaitan dengan keyakinan prinsipil manusia yang di Indonesia bisa mencapai 87, 7 \% (229 juta) dari jumlah penduduk 263 Juta (FR., 2020). Postur penduduk yang mayoritas tersebut sangat rentan untuk digerakan oleh aliansi kelas melalui propaganda -propaganda politik tentang kekalahan ekonomi dan politik sehingga dapat menggerakan emosi kolektif umat islam. Sebab itulah agar aliansinya terus terpelihara diperlukan musuh bersama dan di indonesia personifikasi tersebut terekam dalam diksi penguatan pribumi dan anti-China.

Di Indonesia seperti temuan Freer (2018) populisme islam berbeda corak dengan di Timur Tengah (Mesir dan Turki) yang berpatronkan elit pengusaha sehingga eksistensinya sangat terasa. Di Indonesia populisme islam terserap dalam kepentingan 
elit oligarkis untuk kepentingan dukungan politik dan elektoral sehingga gagal membentuk political frontier dan identitas umat yang hegemonik (Widyanto, 2017).

Di indonesia Ikatan gerakan populisme islam dan elit oligarkis sangat intens dan mutualisme. Kekuatan populisme islam butuh panggung politik dan dukungan finansial sedangkan elit oligarkis butuh dukungan suara. Ikatan pragmatis ini mengakibatkan dukungan populisme pada aktor politik bukan bertumpu pada seberapa kuat basis ideologis islam aktor yang didukung namun sejauhmana agenda politik sebagai cerminan paltfom politik yang dianut dapat diperjuangkan oleh elit politik tersebut. Itulah kemudian mengapa Prabowo yang punya rekam jejak penuh kontradiksi dan oleh sebagian orang diragukan kualitas keislamanya tetap di dukung. Prabowo dianggap pesaing politik paling potensial mengalahkan Jokowi yang diasosisikan sebagai musuh bersama karena dituduh anti islam, dekat dengan china dan komunis (musuh islam) dan dapat menghalangi agenda-agenda besar mereka lainya. Fleksibilitas seperti ini menunjukan betapa pragmatisnya populisme islam yang dibangun bukan atas dasar kesamaan garis ideologis dan karena misi politik.

Agar memberikan pehamanan yang jelas perlu terlebih dahulu diuraikan karakteristik populisme islam jokowi dan prabowo. Pemetaan tersebut bertujuan melihat basis ideologis dan prakis populisme islam yang diterapkan keduanya. Ideologis berkaitan seberapa murni orientasi populisme islam yang diterapkan untuk mengakomodir kepentingan umat dan prakis berguna melihat strategi menunggangi populisme islam demi mobilisasi suara.

Jokowi adalah bukti bahwa politik populisme bekerja efektif dalam menciptakan kecermelangan karir politik aktor lokal pasca desentralisasi. Memulai karir sebagai walikota Solo dua periode 2015-2012 berlanjut Gubernur Jakarta 2012-2014 dan kini Presiden Indonesia 2014-2020 Jokowi mampu mengkapitalisasi citra pemimpin populis dalam dirinya untuk meraih dukungan masyarakat. Karakter populis jokowi terlihat jelas dari pendekatan kepemimpinan dan gaya politik yang dilakukan sehingga membentuk karakter pemimpin merakyat dan sederhana denga model pemimpin alternatif terhadap kecenderungan gaya-gaya elitis dan berjarak pemimpin populer di Indonesia. Citra ini semakin dikokohkan atas fakta bahwa Jokowi tidak berasal dari trah tokoh politik kuat dan oligarkis bisnis sehingga semakin mengesesankan persepsi pemimpin yang lahir langsung dari rahim rakyat.

Predikat sebagai figur populis mulai melekat di Jokowi ketika memimpin Solo 2015-2012. Setidaknya ada tiga peristiwa penting yang melambungkan citra populis Jokowi. Pertama, keberhasilan relokasi Pedagang Kali Lima (PKL) di Monumen 45 Banjarsari dengan damai tanpa konflik (Ariefyanto, 2012). Berbekal budaya jawa yang kuat, Jokowi mempraktekan pendekatan kemanusiaan dengan istilah nguwonke wong yang bertumpu pada dialog. Jokowi menciptakan ruang deliberatif dimana terjadi dialog intensif penuh kekeluargaan antara pedagang dengan pemerintah. Jokowi menununjukan keluwesan komunikasi publik dan perhatian pada PKL dengan tidak melakukan penggusuran seperti lazimnya di kepala daerah lainya.

Jokowi menumbuhkan kesadaran pentingnya penataan PKL demi kepentingan publik bersama dan terbukti berhasil setelah melalui proses komunikasi yang panjang selama 7 (tujuh) bulan dan 45 (empat puluh lima kali) kali makan saiang. Hasilnya Relokasi berlangsung sangat meriah yang justru dilakukan melalui pawai. Jokowi 
menunjukan kepada publik bahwa penyelesaian konflik bisa ditangani dengan sempurna melalui dialog dan partisipasi publik. Kedua, keberanian Jokowi menolak pendirian mall di lokasi bekas pabrik Es Saripetojo dengan alasan membatasi maraknya pasar modern dan melindungi pasar tradisional. Ketiga, gaya blusukan dengan maksud menyerap secara langsung aspirasi masyarakat dan media pengawasan langsung dari pihak pemerintah terhadap suatu program. Melalui program blusukan ini pula citra Jokowi sebagai bagian dari rakyat kecil semakin menguat dalam pentas politik nasional. Kesimpulanya selama memimpin Solo 2005-2012 Jokowi mampu membangun legitimasi politiknya secara demokratis melalui kebijakan yang efektif dan gaya kepemimpinan yang inklusif. Komunikasi politik Jokowi sangat luwes sehingga beberapa kebijakan populernya mampu mengakomodir semua kepentingan khususnya elit yang merasa eksistensinya tidak terancam (Mas' udi, 2017).

Modal politik sebagai pemimpin populis itu pula yang berhasil mengantarkan Jokowi menjadi Gubernur DKI Jakarta 2012. Saat itu pesona populis Jokowi dilengkapi dengan startegi kampanye politik yang milenial dan persuasif (blusukan) berhasil mengalahkan petahana Fauzi Bowo yang didukung oleh oligarkis politik dan bisnis kuat di Jakarta. Jokowi mampu menghadirkan optimisme terhadap perbaikan masalah klasik Jakarta: Banjir, penggusuran dan Kemacetan. Reputasi dan rekam jejak keberhasilan program kepemimpinan yang diperagakan Jokowi di Solo menjadi salah satu kunci utama dibalik keberhasilanya mengungguli petahana Fauzi Bowo di Pilkada DKI Jakarta 2012. Berpasangan dengan Basuki Tjahya Purnama (BTP) pada putaran kedua, keduanya memperoleh 2.472.130 (53,82\%) sedangkan lawanya Fauzi Bowo -Nachrowi Romli sebesar $2.120 .815(46,18 \%)$.

Berbekal reputasi mentereng Jokowi yang berpasangan dengan Jusuf Kalla memenangkan Pilpres 2014. Didukung koalisi PDIP, PDI-P, PKB, Partai NasDem, Partai Hanura, dan PKP Indonesia (Koalisi Indonesia Hebat) Jokowi berhasil 70.997.85 suara (53,15 persen) pada Pemilu Presiden 2014. Jumlah itu berselisih 8.421 .389 suara dari pasangan Prabowo Subianto-Hatta Rajasa, yang meraih 62.576 .444 suara $(46,85$ persen). Kemenangan ini lagi-lagi mempertegas efek politik popolis Jokowi yang disukai oleh banyak pemilih karena kesan tidak berjarak yang dihasilkan dalam dirinya dan program-progam populis yang ditawarkan.

Sebagai pemimpin dengan kultur jawa yang khas dan kental, karakter populisme Jokowi ditampilkan dengan narasi sederhana dan soft spoken. Mietzner (2015) menyebut kekuatan populisme Jokowi terletak dari tawaran sikap politiknya yang rendah hati, sopan, mengedepankan etika kerja keras, spontan, serta kontra-naratif dengan arogansi - tanpa mengkonfrontasi hal tersebut. Dalam menawarkan solusi atas tersoalan masyarakat, Jokowi yang memang lahir dari proses demokratisasi menawarkan konsep lebih demokratis melalui konsep blusukan dan dialog.

Apa yang dilakukan oleh Jokowi sangat mirip dengan retorika kampanye Obama pada Pilpres 2008 dan terbukti menang. Keduanya memiliki kesamaan yakni dipandang sebagai calon pemimpin yang mampu membawa perubahan dalam hal kesetaraan askes politik, ekonomi dan kesejahteraan. Keduanya dengan kemampuan memahami persoalan secara detail karena pengalaman terlibat dalam dunia birokrasi dianggap lebih cakap untuk menyelesaikan persoalan dengan baik. Jokowi dan Barak Obama menawarkan konsep pembangunan yang inklusif berfokus pada pemerataan 
kesejahteraan, serta memberikan jaminan bagi semua orang bahwa mereka mempunyai hak yang sama secara politik dan ekonomi, tanpa takut didominasi oleh kelompok elite tertentu.

Kememangan Jokowi khususnya pada pilgub DKI Jakarta 2012 dan Pilpres 2014 sangat ditentukan dari populisme teknokratnya yang efektif dalam merangkul dukungan mayoritas masyarakat khususnya kelas bawah. Kelebihan utama dari populisme jenis ini terletak pada kemampuanya mereformasi kerusakan sistem secara teratur berdasarkan kalkuasi yang terukur bukan merubah drastis dengan kerja-kerja spesifik dan taktis. Ini tidak terlepas dari pengalamanya sebagai kepala daerah Solo dan DKI Jakarta sehingga solusi yang ditawarkan sangat teknis dan jelas bukan hanya sekedar konsep yang justru tidak bisa diukur manfaatnya.

Jokowi seperti kata Weyland (2001) mampu mengaplikasikan dengan sempurna populisme sebagai startegi politik. Karakter personal Jokowi yang dikenal humanis mampu membangun dukungan secara langsung dari masyarakat. Citra merakyat Jokowi mampu menghidupkan simpul-simpul masyarakat yang tidak terikat organisasi apapun. Itulah sebabnya pada tahun 2014 kemenangan Jokowi juga sangat ditopang oleh gerakan volunterisme dalam pandangan Sihidi (2017) yang sporadis-tidak terafiliasi dengan partai politik atau kelompok politik tertentu. Penjelasan Sihidi (2019) bahwa saat Party-ID indonesia yang terus melemah pasca gelombang demokratisasi 1998 , Jokowi berhasil menggelorakan semangat volunterisme lintas kelas sosial dibalik kemenanganya pada Pilpres 2014.

Pada putaran kedua, Jokowi merubah karakter populisme nya untuk membendung semakin menguatnya populisme islam di Indonesia. Jokowi paham bahwa populisme teknokratnya akan kalah jika tidak mengadopsi nilai-nilai islam yang saat itu sedang menguat khususnya pasca kekalahan Basuki Tjahja Purnama (BTP) selaku sekutu politik terdekatnya pada Pilkada DKI Jakarta 2017. Dengan alasan itulah Jokowi melakukan adaptasi untuk memfigurkan dirinya tidak anti islam melalui safari politik ke banyak pesantren, merangkul ulama dan tentu saja menjadikan Maa'ruf Amin sebagai calon wakil presidenya. Populisme islam Jokowi ditunjukan bukan dengan cara mengeksploitasi sentimen China secara spesifik. Untuk menunjukan keperdulianya pada islam ditunjukan dengan merangkul kelompok-kelompok islam nasionalis dan tradisional dan memberikan program-program populis pro islam melalui penguatan ekonomi keumatan misalnya melalui Pembentukan Badan Pengembangan Ekonomis Syariah. Lembaga ini bertugas mengembangkan produk keuangan syariah dalam negeri dan wisata halal.

Berbeda dengan Jokowi yang lahir bukan dari elit politik kuat, Prabowo adalah bagian dari aristokrat dan oligarkis itu sendiri sehingga ditempatkan sebagai oligarch populism (Aspinall, 2017). Dengan kekayaan yang melimpah model populisme seperti ini juga dapat dinamai dengan pluto populisme karena mempropagandakan populisme secara masif di ruang publik dengan menuduh elit korup sebagai dalang utama dibalik terjadinya ketimpangan sosial dan ekonomi di Indonesia. Narasinya sangat ofensif berkisar pada upaya penghancuran eksistensi kejayaan elit-elit korup tersebut. Model ini sama dengan yang dilakukan oleh Thaksin Sinawarta (Thailand) dan Hugo Chavez (Bolivia) yang disaat bersamaan dikritik karena dasar argumentasinya lemah dan bias sebab mereka merupakan bagian dari elit itu sendiri. Startegi blame game 
mengkambinghitamkan pihak lain adalah contoh betapa oportunisnya politik populisme seperti ini.

Retorika populisme prabowo sering dituduh ultranasionalis. Untuk menimbulkan kesan betapa buruknya kepempimpinan dan menegaskan urgensi kehadiranya, Prabowo menuding keterlibatan asing dan perilaku segelintir elit korup. Itulah sebanya prabowo mengekploitasi hilangnya pendapatan kekayaan nasional akibat cengkarama asing, utang asing yang semakin meningkat, pertumbuhan ekonomi yang melambat dan tidak merata. Prabowo berusaha mereplikasi gaya orasi Soekarno menyebut penderitaan rakyat kecil karena intervensi imperialisme dan kolonialisme (Fossati, 2019). Prabowo hadir dengan semangat nasionalisme yang melanggengkan polarisasi masyarakat karena narasi kampanye yang penuh tuduhan pada kelompok tertentu. Konten narasi Prabowo semakin meningkatkan sentimen anti china melalui kampanye penguatan pribumi dan kebangkitan PKI. Karena itulah populisme Prabowo bergerak sangat kekananan sehingga sangat dekat dengan authoritarian populist.

Prabowo memang dikritik karena imajinasi kampanye politiknya yang penuh kontradiksi (Nazir, 2019). Selain fakta bahwa dirinya merupakan bagian dari elit yang juga berkontribusi pada kekacauan pengelolaan kekuasaan negara selama ini (anak mantu soeharto), kampanye-kampanye politik prabowo yang sangat bombastis acapkali dibumbuhi data dan analisis yang tida akurat. Namun yang patut diingat bahwa pola seperti itu sengaja dilakukan selain untuk mengumpulkan perhatian publik juga menyasar efek psikologis publik yang memang punya kesan negatif terhadap kehadiran utang asing dan etnis China. Dengan mengeksploitasi ketakutan kolektif, data dan fakta menjadi tidak penting karena ungkapan tersebut mengkonfirmasi perspektif negatif terhadap mereka. Belum lagi era post-truth semakin mempersulit masyarakat untuk memvreifikasi sebuah kebenaran sehingga hoax sering menjadi rujukan kebenaran untuk menjustifikasi sikap dan keyakinan politik masyarakat.

Untuk lebih mengesankan kegentingan situasi efek dramatisir selalu dilakukan Prabowo dihampir setiap kampanye politiknya. Hal in terlihat dari pidato politik dan pernyataan-pernyataan kontoversial yang bertujuan memobilisasi dukungan dengan menimbulkan efek ketakutan akan ancaman kebangkitan PKI dan dominasi asing melalui utang. Ekspresi tersebut terus saja diulang-ulang untuk menimbulkan kesan kepanikan dan mempertegas buruknya kualitas pemerintahaan sehingga dirinya pantas menjadi pemimpin.

Semangat prabowo begitu terlihat dari ekspresi nya di depan publik yang sangat berapi-api. Prabowo selalu menuding bahwa belum lepasnya Indonesia dari status negara berkembang karena konspirasi negara asing dan ulah elit-elit korup. Prabowo menjanjikan perubahan fundamental dengan melakukan reformasi besar-besaran dalam setiap aspek demi kepentingan nasional. Nasionalisme yang digelorakan Prabowo ditujukan untuk melayani kepentingan rakyat kecil-kelompok terpinggrikan yang selama ini tidak mendapat kue pembangunan ekonomi akibat keserakahan elit korup. Prabowo menjanjikan distribusi kesejahteraan yang lebih adil dan mengutamakan orang banyak.

Secara tidak langsung Prabowo berusaha merepresentasikan jawaban atas kegelisahan mayoritas rakyat indonesia yang notabene adalah islam. Untuk semakin menguatkan keberpihakan tersebut Prabowo mendekati gerakan-gerakan islam politik khususnya Front Pembela Islam dan Gerakan 212 yang memang secara konsisten selalu 
menggaungkan kata-kata atas nama umat islam dalam setiap perjuanganya khususnya ketika melawan Jokowi. Rezim Jokowi lewat serangkaian kebijakannya dituding anti islam dan ulama sehingga isu tersebut terus di reproduksi untuk menghimpun suara mayoritas islam.

Penetrasi gerakan 212 dan anarsirnya inilah yang semakin menegaskan kesan populisme islam Jokowi gerak pendulumnya sangat kekanan. Mereka menamai dirinya Gerakan Nasional Pembela Fatwa (GNPF) Ulama yang terus aktif menyuarakan ketimpangan yang dialami oleh umat islam di bawah kepemimpinan Jokowi. Mereka begitu gencar memproduksi isu dan wacana mengenai antipati Jokowi pada umat islam dengan membuka ruang bagi kehadiran PKI,meningkatnya pengaruh China dalam ekonomi Indonesia dan melakukan kriminalisasi pada ulama. Sebab itu Jokowi perlu diganti oleh pemimpin yang patuh pada suara ulama dan itu ada di Prabowo. Tindakan Prabowo yang selalu mempertimbangkan rekomendasi ulama-ulama dari kelompok tersebut semakin menunjukan ketergantungannya pada dukungan total kelompok ini.

\section{Jokowi adalah Pemenangnya}

Pemilihan Presiden dilaksanakan serentak dengan pemilihan legislatif pada tanggal 19 April 2019. Kompetisi elektoral yang menghadirkan rematch antara Jokowi dan Prabowo ini dianggap sebagai formula baru sekaligus tonggak perubahan besar dalam sistem pemilu di Indonesia. Format pemilu borongan seperti ini diinisiasi untuk memperkuat sistem presidensil (Solihah, 2018). Setelah melalui masa kampanye yang sangat panjang ( 7 bulan) dengan eksek negatif terjadinya polarisasi esktrem di tingkat akar rumput, pasangan Jokowi-Ma'ruf Amin keluar sebagai pemenang- menggungguli pasangan Prabowo-Subianto dengan selisih suara cukup besar 16.957.123. Dari total suara sah nasional sebesar 154.257.601Jokowi-Ma'ruf berhasil memperoleh 85.607.362 $(55,50)$ Sementara pasangan capres-cawapres nomor urut 02 Prabowo SubiantoSandiaga Uno 68.650.239 suara atau 44,50 persen dari total suara sah nasional.

Didukung oleh koalisi dari 9 partai (Koalisi Indonesia Maju) yakni PDIP, PKB, Golkar, Perindo, NasDem, Hanura, PKPI, PSI, dan PPP berhasil unggul di 21 Propinsi. Adapaun Prabowo-Sandi yang didukung oleh Gerindra, PKS, Demokrat dan PAN (Koalisi Indonesia Adil Makmur) hanya unggul di 13 Propinsi. Jokowi -Ma'ruf Amin setidaknya unggul telak di Jawa Timur, Yogyakarta, Jawa Tengah, Bali, NTT, Papua, Papua Barat dan Sulawesi Utara. Sebaliknya Prabowo-Sandi unggul telak di Sumatera Barat, Kalimantan Selatan, NTB, Banten, dan Jawa Barat. Dari konfigurasi hasil perolehan suara tersebut dapat dijadikan pijakan untuk melihat seberapa besar efektifitas populisme islam terhadap suara yang diperoleh masing-masing kandidat. Hal ini tentunya sangat bergantung dari startegi politik populisme yang dilakukan, karakter wilayah dan pemilih yang sangat menentukan derajat penerimaan terhadap narasi populisme islam yang dihasilkan. 
Tabel 1 Hasil Pilpres 2019

\begin{tabular}{|l|c|c|}
\hline Propinsi & Jokowi-Jusuf Kala & Prabowo-Hata \\
\hline Bali & $2.351 .057(91,68 \%)$ & $213.415(8,32 \%)$ \\
\hline $\begin{array}{l}\text { Nusa Tenggara } \\
\text { Timur (NTT) }\end{array}$ & $2.368 .98(88,57 \%)$ & $305.587(11,43 \%)$ \\
\hline Jawa Timur & $16.231 .668(65,79 \%)$ & $8.441 .247(34,21 \%)$ \\
\hline Jawa Tengah & $16.825 .511(77.29 \%)$ & $944.447(22,71 \%)$ \\
\hline Jawa Barat & $10.750 .568(40,07 \%)$ & $16.077 .446(59,93 \%)$ \\
\hline Sumatera Barat & $407.761(14,08 \%)$ & $2.488 .733(85,92 \%)$ \\
\hline Aceh & $404.188(14,41 \%)$ & $2.400 .746(85,59 \%)$ \\
\hline Banten & $2.537 .524(38,46 \%)$ & $4.059 .514(61,54 \%)$ \\
\hline Kalimantan Selatan & $823.939(35,92 \%)$ & $1.470 .163(64.08 \%)$ \\
\hline Papua & $3.021 .713(90,66 \%)$ & $311.352(9,34 \%)$ \\
\hline Papua Barat & $508.997(79,81 \%)$ & $128.732(20,19 \%)$ \\
\hline Sulawesi Utara & $1.220 .524(77,24 \%)$ & $359.685(22,76 \%)$ \\
\hline & & \\
\hline
\end{tabular}

Sumber: KPU RI (2019)

Karakter populisme islam baik Jokowi dan Prabowo sangat berkaitan dengan platfom politik yang diusung beserta konfigurasi politik yang didapatkan. Pengaruh keduanya sangat terlihat dari narasi populisme yang disampaikan dan perilaku politik yang ditunjukan. Meskipun harus diakui populisme islam yang dimainkan bersifat pragmatis demi kemenangan elektoral bukan karena pijakan ideologis.

Sebagai petahana dengan jejak propaganda hitam sejak pencapresan 2014; anti islam, anti ulama dan memberi ruang hidupnya komunisme, Jokowi sebetulnya tidak memberikan perhatian khusus berlebihan sebelum momentum kemenangan pasangan Anies-Sandi pada Pilkada DKI Jakarta 2017. Kemenangan tersebut membuktikan sentimen islam sangat berpengaruh dalam Pilkada. Kemenangan Anies-Sandi yang didukung penuh oleh golongan islam konservatif dengan mengarusutamakan identitas adalah bukti besarnya pengaruh mereka dalam politik indonesia.

Pilkada DKI Jakarta sebagai pertanda penting kebangkitan populisme islam konservatif membuat Jokowi melakukan beberapa startegi politik penyesuaian untuk 
membendung inflitrasi mereka di ruang-ruang publik dan politik Indonesia. Jokowi sadar bahwa agama karena sifatnya yang sangat prinsipil bagi pemilih jika tidak dikelola dengan baik akan memicu kekalahanya pada Pilpres 2019. Jokowi sadar bahwa modal kepopuleran dan elektabilitas yang dimilikinya sangat mungkin jatuh jika terus-terus diserang agama apalagi di era post truth seperti ini.

Kalkulasi politik Jokowi untuk terus menunjukan keberpihakanya pada islam sebagai agama mayoritras ditunjukan dalam beberapa hal seperti mengunjungi banyak pesantren, membangun kedekatan dengan Tuan Guru Bajang yang juga masuk nominasi sebagai calon Wakil Presiden dan tentu saja memilih Ma'aruf Amin sebagai calon Wakil Presidenya. Status Mar'aruf amin sebagai ulama setidaknya memberikan tiga manfaat penting bagi Jokowi. Pertama, menarik dan menyolidkan suara Nahdatul ulama (NU) yang diperkirakan 60 persen dari total seluruh pemilih di Indonesia. Kedua, menepis sentimen anti ulama yang selama ini menjadi titik lemah yang terus diporpagandakan oleh lawan-lawan politiknya.

Di pihak lain, Prabowo mengambil jalan populisme islam dengan membangun afiliasi dengan kekuatan-kekuatan islam politik konservatif. Prabowo sangat mungkin terinspirasi dengan kemenangan Anies-Sandi mengalahkan petahana Ahok-Djarot yang selalu unggul jauh dalam survei elektabilitas namun rontok karena isu agama. Saat itu memang ada dugaan bahwa berkaca dari ampuhnya populisme islam di Jakarta, strategi membelah seperti ini akan terus dirawat dan dipermanenkan di momen-momen politik selanjutnya khususnya nasional (Arifin, 2019). Terbukti, itu betul-betul direpiklasi oleh Prabowo di 2019.

Kunci penting untuk menunjukan orientasi populisme islam Prabowo adalah dengan pilihanya membangun kedekatan dengan organisasi islam konservatif. Terdapat tiga tokoh penting dalam struktur Badan Pemenangan Nasional (BPN) Prabowo-Sandi yang merupakan anarsir islam konservatif yakni Slamet Ma'arif Slamet selaku Juru Bicara FPI dan Ketua Presidium Alumni Aksi Bela Islam 212 (Wakil Ketua BPN), Abdul Rasyid Abdullah Syafi'i sebagai Wakil Ketua Dewan Penasihat BPN yang merupakan Pengasuh pondok dan lembaga pendidikan As-Syafi'iyah sekaligus Dewan Penasehat Koperasi Syariah 212 dan pernah menjadi Ketua pengarah panitia Ijtima Ulama II dan Yusuf Muhammad Martak (Dewan Pengarah BPN) yang sekaligus Yusuf merupakan Ketua Umum Gerakan Nasional Pengawal Fatwa Ulama (GNPF-Ulama) (Erdianto, 2018).

Selanjutnya narasi kampanye yang dilakukan keduanya juga berbeda. Jokowi dan Ma'ruf Amin lebih menggaungkan islam nusantara yang secara sosiologis dan keagamaan merangkul pluralisme dan islam moderat di Indonesia. Islam nusantara yang dimaksud mampu merangkul semangat keindonesiaan yang plural, seirama dengan pancasila dan tentu lebih dianggap memberikan perlindungan pada minoritas. Sedangkan prabowo yang notabene terlalu dekat dengan islam konservatif narasi kampanye nya sangat dipengaruhi oleh agenda-agenda keagamaan sesuai corak islam konservatif (NKRI bersyariah). Ini belum lagi dukungan Hizbut Tahrir Indonesia ( $\mathrm{HTI}$ ) yang 
sebelum dibubabarkan oleh Jokowi melalui Peraturan Pemerintah Pengganti Undangundang (Perppu) Nomor 2 Tahun 2017 secara intensif dan terang-terangan bergerilya untuk tegaknya khilafah di Indonesia. Dukungan totalitas kaum konservatif yang juga tergabung dalam tim inti membuat populisme islam Prabowo begitu menakutkan bagi golongan islam tradisionalis (NU), kaum nasionalis dan minoritas.

Tabel 1 (satu) di atas menunjukan bahwa Pilpres 2019 adalah panggung keberhasilan populisme islam Jokowi. Pertama, keberhasilan Jokowi sangat ditentukan oleh Mar'tuf Amin sebagai simbol ulama (Rais Aam PBNU) yang mampu mengkonsolidasikan suara Nahdatul Ulama (NU). Sebagai bukti Jokowi berhasil menaikan margin kemenangan dari Pilpres 2014 di Jawa Timur dan Jawa Tengah (tabel II) yang selama ini dikenal sebagai basis suara NU. Khusus Jawa Tengah dukungan Habib Luthfi dan Mbah Moen ke Jokowi yang sebelumnya pendukung Prabowo sangat berkontribusi terhadap kemenangan Jokowi. Disisi lain kompaknya dukungan elit kuat NU pada Jokowi selain karena faktor Ma'ruf Amin juga didasarkan kedekatan Prabowo dengan kekuatan islam-islam konservatif yang dekat dengan gerakan radikal untuk merubah pancasila. Cita-cita tersebut tentunya bertentangan dengan semangat NU untuk menjaga keindonesiaan dalam balutan pancasila. Hal ini terkonfirmasi jelas dari Data exit poll Indikator Politik Indonesia yang menunjukkan ada peningkatan dukungan NU terhadap Jokowi sebesar 12 \% dari tahun 2014 ke 2019 (Idris, 2019).

Kedua, Jokowi menang telak di daerah-daerah dengan mayoritas pemilih nonmuslim, seperti yang terjadi di Bali, NTT, dan kawasan timur Indonesia lainnya (papua, papua Barat dan Sulawesi Utara0. Margin kemenanganya juga meningkat di banding tahun 2014 (tabel II) salah satunya karena ketakutan akan peluang formalisasi islam dalam kehidupan bernegara jika Prabowo terpilih.

Ketiga prabowo menang telak di daerah-daerah dengan karakteristik kekuatan kelompok islam kental (Jawa Barat, Sumatera Barat, Aceh, Banten, dan Kalimantan Selatan). Aceh, Suamtera Barat dan Kalimantan Selatan margin kemenangan Prabowo cukup meningkat drastis di banding tahun 2014 (tabel II). Daerah-daerah tersebut dikenal menjadi lumbung suara loyal bagi Prabowo dan cenderung mengidolai ustadz kondang seperti Abdul Somad (pendukung Prabowo). Hal ini juga diperkuat temuan Alvara Search (2019) yang menyimpulkan semakin tinggi penduduk muslim di suatu daerah, semakin kecil pula keterpilihan Jokowi (Widiastuti, 2019). 
TABEL 2 Hasil Pilpres 2014

\begin{tabular}{|l|l|l|}
\hline Propinsi & Jokowi-Jusuf Kala & Prabowo-Hata \\
\hline Bali & $1.535 .110(71,42 \%)$ & $614.241(28,58 \%)$ \\
\hline $\begin{array}{l}\text { Nusa Tenggara } \\
\text { Timur (NTT) }\end{array}$ & $1.528 .783(66,12 \%)$ & $783.514(33,88 \%)$ \\
\hline Jawa Timur & $11.669 .313(53,17 \%)$ & $10.277 .088(46,83 \%)$ \\
\hline Jawa Tengah & $12.959 .540(66,65 \%)$ & $6.485 .720(33,35 \%)$ \\
\hline Jawa Barat & $9.530 .315(40,22 \%)$ & $14.167 .381(59,78 \%)$ \\
\hline Sumatera Barat & $539.308(23,08 \%)$ & $1.797 .505(76,92 \%)$ \\
\hline Aceh & $913.309(45,61 \%)$ & $1.089 .290(54,39 \%)$ \\
\hline Banten & $2.398 .631(42,90 \%)$ & $3.192 .671(57,10 \%)$ \\
\hline Kalimantan Selatan & $939.748(49,95 \%)$ & $941.809(50,05 \%)$ \\
\hline Papua & $2.058 .517(73,16 \%)$ & $755.374(26,84 \%)$ \\
\hline Papua Barat & $360.381(67,51 \%)$ & $73.428(32,49 \%)$ \\
\hline Sulawesi Utara & $724.553(53,88 \%)$ & $620.095(46,12 \%)$ \\
\hline
\end{tabular}

Sumber: diolah dari berbagai sumber

Dari semua provinsi yang tertera di tabel 1 (satu) persebaran kemenangan kedua kandidat baik Jokowi - Ma'ruf Amin dan Prabowo- Sandi memang tidak terlepas dari taktik populisme islam yang digunakan. Namun itu bukan merupakan variabel tunggal yang telah terjadi. Kerja-kerja partai politik pendukung dan relawan juga turut serta menggaet suara pemilih islam sebab tidak semua pemilih di Indonesia menjadikan agama sebagai basis utama dalam menentukan pilihan. Dengan demikian artikel ini tidak mengklaim bahwa agama (populisme islam) menjadi kontributor tunggal. Kerja-kerja kampanye pemenangan kreatif yang dilakukan mesin partai politik dan relawan juga turut andil mendorong kemenangan keduanya.

\section{Penutup}

Hasil pemilu 2019 mengkonformasi betapa kuatnya politik identitas dalam mempengaruhi preferensi pemilih. Meskipun bukan faktor tunggal karena ada kontribusi misalnya mesin partai politik dan relawan namun ekploitasi identitas seperti ini cukup signifikan dalam memberikan kemenangan untuk Jokowi dan Prabowo di beberapa tempat. Kemampuannya yang sangat fatal dalam mengoyak-ngoyak emosi publik memang sangat berbahaya bagi kohesifitas bangsa Indonesia namun tetap akan 
dipergunakan sebagai strategi mobilisasi dukungan dalam momen elektoral. Selama ketimpangan ekonomi dan status sosial masih membayangi dan disaat bersamaan kekuatan oligarkis butuh suara, gelora populisme islam akan terus terjadi. Persinggungan kepentingan keduanya yang terus berlangsung akan semakin mengentalkan pragmatisme dalam politik karena agama yang seharusnya menjadi katalisator praktek politik buruk justru dimanfaatkan untuk melegitimasi satu kepentingan politik yang orientasi utamanya berkuasa bukan demi kepentingan umat islam.

Pilpres 2019 adalah panggung dimana Jokowi berhasil lolos dari jebakan populisme islam yang diperagakan oleh Prabowo dan pendukungnya karena strategi jalan keluarnya yang cerdas. Ma'ruf Amin dipilih bukan karena kapasitas kepemimpinanya untuk mendukung kelanjutan program-program populis pembangunan Jokowi-namun sebagai penetral atas stigma anti-islam yang selama ini dilekatkan pada Jokowi oleh musuh-musuh politiknya. Pendekatan pragmatisme seperti ini persis dengan yang dilakukan oleh prabowo dalam membangung relasi dengan kelompok islam konservatif.

Pilpres 2019 memang masih menunjukan kemenangan kelompok islam moderat dan anarsirnya dalam merebut pengaruh pemilih. Namun yang patut diingat konsolidasi populisme islam ala kelompok konservatif tidak berhenti sampai disitu. Mereka akan selalu ada sebagai kelompok kepentingan, terus mengamati dan menunggu momentum yang pas untuk memperluas pengaruhnya. Mereka akan selalu berusaha menempel pada aktor politik yang punya misi politik sama, memiliki sumber daya finansial yang kuat karena mereka sadar bahwa demokrasi Indonesia padat modal dan menggerakan 'umat' butuh biaya sangat besar.

\section{Ucapan terima kasih}

Penulis menyampaikan terima kasih terhadap rekan-rekan penulis di Program Studi Ilmu Pemerintahan dan Hubungan Internasional Universitas Muhammadiyah Malang yang banyak berkontribusi terhadap penyusunan naskah ini.

\section{Pendanaan}

Artikel ini didanai secara mandiri oleh para penulis.

\section{Daftar Pustaka}

Ariefyanto, M. I. (2012). Mengenal Jokowi, Pahlawan PKL di Solo. Retrieved from https://www.republika.co.id/berita/rol-to-campus/news-rol-to-campus-

2/12/11/11/mdbcdw-mengenal-jokowi-pahlawan-pkl-di-solo

Arifin, S. (2019). Islam, Populisme dan Masa Depan Demokrasi di Indonesia. Maarif, 14(1), 9-28.

Aslanidis, P. (2016). Is Populism an Ideology? A Refutation and a new Perspective. Political Studies, 64(1_suppl), 88-104.

Aspinall, E. (2017). Oligarchic Populism : Prabowo Subianto 's Challenge to Indonesian Democracy. Indonesia 99, (April 2015), 1-28. https://doi.org/10.1353/ind.2015.0002

Conniff, M. L. (2012). Populism in Latin America: Second Edition 2nd Edition. Alabama: 
The University of Alabama Press.

Erdianto, K. (2018). Tokoh GNPF, FPI dan PA 212 Tempati Posisi Strategis di BPN Prabowo-Sandiaga. Kompas.Com.

Ernesto, L. (2005). On Populist Reason. London: Verso.

Fossati, M. (2019). Analyzing Indonesia's Populist Electorate Demographic, Ideological , and Attitudinal Trends. Asian Survey, 59(5), 769-794.

FR., Y. (2020). Data Populasi Penduduk Muslim 2020: Indonesia Terbesar di Dunia. Retrieved from https://ibtimes.id/data-populasi-penduduk-muslim-2020indonesia-terbesar-di-dunia/

Freer, C. (2018). Vedi R. Hadiz, Islamic Populism in Indonesia and the Middle East. Middle Eastern Studies ISSN:, https://doi.org/10.1080/00263206.2018.1483918

Hadiz, V. R. (2013). A New Islamic Populism and the Contradictions of Development A New Islamic Populism and the Contradictions of Development. Journal OfContemporary Asia, (August), 1-19. https://doi.org/10.1080/00472336.2013.832790

Hadiz, V. R. (2016). Islamic Populism in Indonesia and the Middle East. Cambridge University Press.

Idris, M. (2019). Indikator Politik: Nahdlatul Ulama Jadi Penentu Kemenangan Jokowi. Detik.Com.

Jani, L. (2017). Persenyawaan Politik Identitas dan Populisme Tawaran Kerangka Analisis. Prisma, 36(3), 18.

Jayanto, D. D. (2019). Mempertimbangkan Fenomena Populisme Islam di Indonesia dalam Perspektif Pertarungan Diskursif: Kontestasi Wacana Politik Antara Gerakan Nasional Pengawal Fatwa Ulama (GNPF-Ulama) dan Nahdlatul Ulama (NU). Jurnal Filsafat, 29(1), 1-25.

Kenny, C. H. and P. D. (2017). Christian Houle and Paul D. Kenny * The Political and Economic Consequences of Populist Rule in Latin America. Government and Opposition, 1-32. https://doi.org/10.1017/gov.2016.25

Kusumo, R. A. N. (2017). Populisme Islam di Indonesia : Studi Kasus Aksi Bela Islam oleh GNPF-MUI Tahun 2016-2017. Jurnal Politik, 4(1), 87-113.

Margiansyah, D. (2019). Populisme di Indonesia Kontemporer: Transformasi Persaingan Populisme dan Konsekuensinya dalam Dinamika Kontestasi Politik Menjelang Pemilu 2019. Jurnal Penelitian Politik, 16(1), 47-68.

Mas' udi, W. (2017). Creating Legitimacy in Decentralized Indonesia: Joko'Jokowi'Widodo's Path to Legitimacy in Solo, 2005-2012.

Mietzner, M. (2015). Reinventing Asian Populism.

Moffitt, B., \& Tormey, S. (2014). Rethinking populism: Politics, Mediatisation and Political Style. Political Studies, 62(2), 381-397.

Mudde, C., \& Kaltwasser, C. R. (2017). Populism: A Very Short Introduction. Oxford University Press.

Mudhoffir, A. M., Yasih, D. W. P., \& Hakim, L. (2017). Populisme Islam dan Tantangan Demokrasi di Indonesia. Prisma, 36(3), 48-59.

Muhtadi, B. (2019). Populisme Politik Identitas \& Dinamika Elektoral (Mengurai Jalan Panjang Demokrasi Prosedural). Malang: Intrans Publishing. 
Nazir, I. (2019). Prabowo dan Bangkitnya Populisme Sayap Kanan di Indonesia. Retrieved from https://tirto.id/prabowo-dan-bangkitnya-populisme-sayap-kanan-diindonesia-dhLf

Panizza, F. (2005). Introduction: Populism and the Mirror of Democracy.

Prayogi, I., \& Adela, F. P. (2019). POLITEIA : Jurnal Ilmu Politik Populisme Islam dan Imajinasi Politik dalam Pilkada DKI Jakarta 2017. Politeia:Jurnal IImu Politik, 11(2), 31-43.

Robison, R., \& Hadiz, V. R. (2004). Reorganising Power in Indonesia: The Politics of Oligarchy in an Age of Markets (Vol. 3). Psychology Press.

Savitri, L. A., \& Adriyati, D. (2018). The Demise of Emancipatory Peasant Politics? Indonesian Fascism and the Rise of Islamic Populism. ERPI.

Sihidi, I. T. (2017). Ekspresi Voluntersisme Politik Studi Teman Ahok Di Pilkada DKI Jakarta 2017. Universitas Gadjah Mada.

Sihidi, I. T. (2019). Relasi Politik Uang dan Party-ID di Indonesia. CosmoGov: Jurnal IImu Pemerintahan, 5(2), 204-220. https://doi.org/Doi: https://doi.org/10.24198/cosmogov.v5i2.23293

Solihah, R. (2018). Peluang dan Tantangan Pemilu Serentak 2019 dalam Perspektif Politik. JIIP: Jurnal IImiah IImu Pemerintahan, 3(1), 73-88.

Weyland, K. (2001). Clarifying a Contested Concept: Populism in the Study of Latin American Politics. Comparative Politics, 1-22.

Widiastuti, R. (2019). Populisme Agama Masih Kuat, Ma'ruf Amin Kunci Kemenangan Jokowi. Tempo.Com.

Widyanto, U. (2017). Populisme Islam (1): Turki Lebih Sukses Dibanding Indonesia. Retrieved from https://nasional.tempo.co/read/838908/populisme-islam-1-turkilebih-sukses-dibanding-indonesia/full\&view=ok

\section{Tentang Penulis}

Iradhad Taqwa adalah dosen Program Studi Ilmu Pemerintahan Universitas Muhammadiyah Malang, Fakultas IImu Sosial dan IImu Politik, Universitas Muhammadiyah Malang. Penulis fokus pada kajian Politik dan Pemilu

Ali Roziqin adalah dosen Program Studi Ilmu Pemerintahan Universitas Muhammadiyah Malang, Fakultas IImu Sosial dan IImu Politik, Universitas Muhmmadiyah Malang. Penulis fokus pada kajian Birokrasi Pemerintahan dan Urban Politik

Dedik Fitrah Suhermanto adalah dosen Program Studi Ilmu Hubungan Internasional Universitas Muhammadiyah Malang, Fakultas IImu Sosial dan IImu Politik, Universitas Muhmmadiyah Malang yang fokus pada politik islam dan studi keamanan. 